\title{
Hubungan antara intensitas penggunaan game online dengan visus pada siswa di SMA
}

\author{
Yoki Oktavani ${ }^{1}$ Tubagus Ferdi Fadilah ${ }^{2}$
}

\begin{abstract}
ABSTRAK
\section{LATAR BELAKANG}

Penglihatan yang optimal hanya dapat dicapai bila terdapat suatu jalur saraf visual yang utuh, struktur mata yang sehat serta kemampuan fokus mata yang tepat. Etiologi dari penurunan visus bersifat multifaktoral. Berdasarkan data dari World Health Organization, diseluruh dunia pada tahun 2010 terdapat sebanyak 285 juta orang (4.24\%) populasi dengan gangguan penglihatan; 39 juta (0.58\%) dengan kebutaan; dan 246 juta (3.65\%) dengan low vision. Penyebab gangguan penglihatan tertinggi di seluruh dunia adalah kelainan refraksi (43\%).

\section{METODE}

Jenis penelitian ini merupakan penelitian analitik observasional dengan pendekatan rancangan potong silang. Penelitian ini bersifat retrospektif dengan menggunakan kuesioner untuk intensitas penggunaan game online dan pemeriksaan menggunakan kartu Snellen serta Pinhole untuk visus di SMAN 23 Tomang, Jakarta Barat. Responden berjumlah 149 orang, analisis data dilakukan secara univariat dan bivariat menggunakan uji Fisher's Exact Test. Analisis diolah dengan program SPSS 21.
\end{abstract}

\section{HASIL}

Uji Fisher's didapatkan nilai probabilitas $\mathrm{p}=0.551$ dimana didapatkan $\mathrm{p}>0.05$, sehingga tidak terdapat hubungan antara intensitas penggunaan game online dengan penurunan visus.

\section{KESIMPULAN}

Tidak terdapat hubungan bermakna antara intensitas penggunaan game online dengan penurunan visus pada siswa kelas X - SMAN 23 Tomang Jakarta Barat.

Kata kunci : game online, visus, remaja, refraksi anomali
${ }^{1}$ Program Studi Kedokteran, Fakultas Kedokteran, Universitas Trisakti

${ }^{2}$ Departemen Ilmu Kesehatan Anak, Fakultas Kedokteran, Universitas Trisakti

\section{Korespondensi:}

Tubagus Ferdi Fadilah

Departemen Ilmu Kesehatan Anak, Fakultas Kedokteran, Universitas Trisakti, Jalan Kyai Tapa No. 260, Grogol, Jakarta Barat.

Email: tb_ferdi_md@trisakti.ac.id

J Biomedika Kesehat 2018;1(3):198202 DOI: 10.18051/JBiomedKes.2018. v1.198-202

pISSN: 2621-539X / eISSN: 2621-5470

Artikel akses terbuka (open access) ini didistribusikan di bawah lisensi Creative Commons Attribution 4.0 International (CC-BY 4.0) 


\section{ABSTRACT}

\section{Relationship between intensity of online gaming and visual acuity in high school students}

\section{BACKGROUND}

Optimal vision can only be achieved when there is an intact visual neural pathway, healthy eye structure and appropriate eye focus capability. The etiology of decrease of the visus is multifactoral. Visus is the ability of the vision system to distinguish between different forms. Based on data from the World Health Organization, worldwide in 2010 there were 285 million people $(4.24 \%)$ of the population with visual impairment; 39 million $(0.58 \%)$ with blindness; and 246 million (3.65\%) with low vision. The most common causes of vision loss worldwide were refractive disorders $(43 \%)$.

\section{METHODS}

The study used observational analytic study with cross-sectional design. This study is a retrospective study by using game online intensity questionnaire and data of visus by using Snellen Chart to senior high school students in SMAN 23 Tomang, West Jakarta. Total respondents are 149 adolescents. The statistical univariate and bivariate analysis was done by Fisher's Exact Test and done with SPSS 21.

\section{RESULT}

Fisher's test obtained probability value $\mathrm{p}=0.551$ which got $\mathrm{p}>0.05$, so there is no relation between intensity of online game usage with decreasing of visus.

\section{CONCLUSION}

There is no significant relationship between the intensity of online game usage with the decrease of visus in the 10th grade class students at SMAN 23 Tomang West Jakarta.

Keywords : online games, visus, adolecents, refraction anomalies

\section{PENDAHULUAN}

Visus (tajam penglihatan) mata merupakan kemampuan sistem penglihatan untuk membedakan berbagai bentuk. ${ }^{(1)}$ Penglihatan yang optimal hanya dapat dicapai bila terdapat suatu jalur saraf visual yang utuh, struktur mata yang sehat serta kemampuan fokus mata yang tepat. Faktor-faktor yang mempengaruhi penurunan visus mata adalah tingkat pencahayaan, ukuran, objek kerja, bentuk objek kerja, kekontrasan, lama waktu untuk melihat objek kerja dan jarak melihat objek kerja. ${ }^{(2)}$

Etiologi dari penurunan tajam visus bersifat multifaktoral. Prevalensi terbesar yang didapatkan pada anak usia sekolah disebabkan karena kelainan refraksi. Berdasarkan data dari World Health Organization (WHO), diseluruh dunia pada tahun 2010 terdapat sebanyak 285 juta orang $(4.24 \%)$ populasi dengan gangguan penglihatan; 39 juta $(0.58 \%)$ dengan kebutaan; dan 246 juta (3.65\%) dengan low vision. Penyebab gangguan penglihatan terbanyak di seluruh dunia adalah kelainan refraksi (43\%), katarak (33\%), dan glukoma $(2 \%){ }^{(3)}$ Prevalensi penurunan penglihatan terparah yang paling tinggi di Indonesia terdapat di Lampung (1.7\%), diikuti Nusa Tenggara Timur, Jawa Tengah, dan Kalimantan Barat (masing-masing $1.6 \%$ ). Provinsi dengan prevalensi penurunan penglihatan terparah yang paling rendah adalah DI Yogyakarta $(0.3 \%)$ diikuti oleh Papua Barat dan Papua (masing-masing 0.4\%). ${ }^{(4)}$

Penyebab kebutaan sangat bervariasi pada setiap negara, salah satunya adalah kelainan refraksi khususnya di Asia Tenggara. ${ }^{(5)}$ Pada pertemuan International Agency for Prevention of Blindness (IAPB) tahun2001, terdapat 5-15\% anak memiliki kelainan refraksi. ${ }^{(6)}$ Menurut Depkes RI didapatkan bahwa kebutaan di Indonesia sebesar 0.6 per seribu anak diantaranya sebesar $10 \%$ dari 66 juta anak usia sekolah (5-19 tahun) menderita kelainan refraksi. ${ }^{(7)}$

Penelitian yang dilakukan oleh Hanum pada tahun 2008 menjelaskan bahwa VDT (Visual Display Terminal) Studies and Information untuk melakukan istirahat selama 15 menit terhadap pemakaian komputer selama 2 jam. Frekuensi istiahat yang teratur berguna untuk memotong rantai kelelahan sehingga akan menambah kenyamanan bagi pengguna komputer. ${ }^{(8)}$ Penelitian lain yang dilakukan oleh Giri pada tahun 2013 menjelaskan bahwa belum banyak penelitian yang membahas mengenai mekanisme spesifik bagaimana mata terpengaruh oleh tingkat intensitas bermain game. Perlu ditelusuri bagaimana patofisiologi dan dampak spesifik yang mempengaruhi tajam penglihatan mata. $^{(9)}$ 
Berdasarkan latar belakang di atas, diketahui bahwa gangguan visus mata pada anak merupakan masalah kesehatan yang menjadi sorotan di masyarakat saat ini. Namun, hubungannya dengan aktivitas bermain game online masih belum dapat dibuktikan sepenuhnya. Oleh karena itu, penulis ingin melakukan penelitian untuk mengetahui visus dan hubungan intensitas penggunaan game online dengan visus pada siswa di SMA.

\section{METODE}

Jenis penelitian ini merupakan penelitian
analitik observasional dengan pendekatan rancangan potong silang. Penelitian ini bersifat retrospektif dengan memanfaatkan data kuesioner mengenai intensitas penggunaan game online dan data visus yang didapatkan dengan pemeriksaan menggunakan kartu Snellen serta Pinhole diSMAN 23 Tomang, Jakarta Barat. Jumlah responden sebanyak 149 orang dengan pengambilan sampel menggunakan teknik Consecutive Non Random Sampling. Analisis data dilakukan secara univariat dan bivariat menggunakan uji Fisher's Exact Test. Analisis diolah dengan program SPSS 21. Sampel penelitian adalah siswa kelas $\mathrm{X}$ yang memenuhi kriteria inklusi berupa; merupakan siswa kelas X SMA 23 Tomang, Jakarta Barat. Kriteria eksklusi sampel penelitian adalah terdapat riwayat trauma pada mata yang menyebabkan penurunan visus dan kelainan anatomis mata, siswa yang menggunakan kacamata atau softlens, tidak bersedia menjadi responden dan siswa yang mengisi data tidak lengkap.

Instrumen yang digunakan dalam penelitian ini adalah Informed consent dan formulir-formulir untuk identitas responden, kuesioner berupa pertanyaan-pertanyaan yang akan diteliti mengenai intensitas penggunaan game online, dan pemeriksaan visus menggunakan kartu Snellen, Pinhole, trial lens dan trial frame. Kuesioner berisi 23 pertanyaan dengan skor masing-masing adalah tidak pernah $=1$, jarang $=2$, sering $=3$ dan selalu=4. Penilaian intensitas penggunaan game online adalah total skor dengan kategori rendah (skor 40-57), sedang (skor 58-74) dam tinggi (skor $>75$ ). ${ }^{(10)}$ Kalsifikasi penilaian visus adalah tajam penglihatan normal (visus $6 / 5$, $6 / 6,6 / 7,5)$, tajam penglihatan hampir normal (visus 6/9, 5/9, 6/12, 6/15, 6/18, 6/21), Gangguan penglihatan sedang $(6 / 24,6 / 30,6 / 40)$ dan gangguan penglihatan berat $(6 / 60,6 / 90,6 / 120)$

Analisis yang dilakukan terbagi menjadi analisis univariat dan bivariat. Analisis univariat dilakukan untuk melihat gambaran distribusi frekuensi pada Intensitas penggunaan game online dan Visus. Analisis bivariat dilakukan untuk melihat adanya hubungan hubungan intensitas penggunaan game online dengan visus menggunakan uji Fisher's Exact. Batas kemaknaan yang digunakan adalah $\mathrm{p}<0.05$. Metode pengolahan dan analisis menggunakan software SPSS (Statistical Program for Social Sciences) versi 21.

\section{HASIL}

Tabel 1. Gambaran karakteristik responden $(n=149)$

\begin{tabular}{lc}
\hline \multicolumn{1}{c}{ Variabel } & $\mathbf{n}(\mathbf{\%})$ \\
\hline Umur & \\
15 tahun & $149(100)$ \\
Intensitas penggunaan game online & \\
Rendah & $126(84.6)$ \\
Sedang & $21(14.1)$ \\
Tinggi & $2(1.3)$ \\
Visus & \\
Normal & $113(75.8)$ \\
Hampir normal & $22(14.8)$ \\
Menurun sedang & $11(7.4)$ \\
Menurun berat & $3(2.0)$ \\
\hline
\end{tabular}

Berdasarkan Tabel 1, seluruh responden berusia 15 tahun. Intensitas penggunaan game online yang tertinggi adalah dengan intensitas rendah yaitu 126 responden (84.6\%). Sebagian besar responden memiliki visus yang normal yaitu 113 responden $(75.8 \%)$.

Berdasarkan Tabel 2 menunjukkan sebagian besar responden (75.4\%) memiliki visus nornal dengan penggunaan game online intensitas rendah. Uji Fisher's didapatkan nilai probabilitas $\mathrm{p}=0.551$ dimana didapatkan $\mathrm{p}>0.05$, sehingga dapat disimpulkan bahwa tidak terdapat hubungan antara intensitas penggunaan game online dengan penurunan visus.

\section{PEMBAHASAN}

Analisis bivariat menggunakan uji Fisher's didapatkan $\mathrm{p}=0.551 \quad(\mathrm{p}>0.05)$ menunjukkan tidak terdapat hubungan antara 
Tabel 2. Cross Tabulation frekuensi intensitas penggunaan game online terhadap penurunan visus

\begin{tabular}{|c|c|c|c|c|c|c|}
\hline & \multicolumn{5}{|c|}{ Visus } & \multirow{2}{*}{$\mathbf{p}$} \\
\hline & & Normal & Hampir Normal & Sedang & Berat & \\
\hline \multirow{2}{*}{$\begin{array}{l}\text { Intensitas } \\
\text { penggunaan game } \\
\text { online }\end{array}$} & Rendah & $95(75.4)$ & $18(14.3)$ & $11(8.7)$ & $2(1.6)$ & \multirow[t]{2}{*}{$0.551 *$} \\
\hline & $\begin{array}{c}\text { Sedang } \\
\text { Tinggi }\end{array}$ & $\begin{array}{c}16(76.2) \\
2(100)\end{array}$ & $\begin{array}{c}4(19) \\
0(0)\end{array}$ & $\begin{array}{l}0(0) \\
0(0)\end{array}$ & $\begin{array}{c}1(4.8) \\
0(0)\end{array}$ & \\
\hline
\end{tabular}

*Uji Fisher's Exact

intensitas penggunaan game online dengan penurunan visus. Hal ini sesuai dengan penelitian yang dilakukan oleh Mondal, $\mathrm{dkk}^{(11)}$, yang menyatakan ada beberapa faktor mengenai kebiasaan responden yang dapat menyebabkan penurunan tajam penglihatan yang belum diketahui. Sama halnya pada penelitian ini yang belum mengetahui apa faktor resiko lain yang dapat menurunkan tajam pengelihatan pada sampel sehingga dapat menimbulkan tidak adanya hubungan antar keduanya.

Penelitian oleh Tina Y, dkk. ${ }^{(12)}$ menyatakan hal serupa yaitu tidak terdapat hubungan antara lamanya memainkan video game tersebut dengan penurunan tajam penglihatan. Hal ini dapat terjadi karena banyak faktor yang mempengaruhi tajam penglihatan saat dilakukannya penelitian. Faktor-faktor tersebut adalah lingkungan laboratorium tempat dilakukannya penelitian, konsumsi makanan ataupun suplemen setiap orang yang berbeda dan lamanya permainan game yang dilakukan diluar penelitian laboratorium. Sama halnya dengan penelitian ini, dalam penelitian tidak diketahui adanya faktor lain yang dapat mempengaruhi tajam penglihatan seperti faktor bawaan atau keturunan, konsumsi vitamin, pencahayaan saat menggunakan media elektronik, dll.

Penelitian oleh Giri dkk ${ }^{(9)}$ menyatakan hal yang berbeda, yaitu terdapat kecendrungan peningkatan jumlah penurunan tajam penglihatan pada siswa laki-laki yang memiliki intensitas bermain game yang lama dan menunjukkan terdapat hubungan antara dua variabel tersebut. Hal ini dapat disebabkan oleh perbedaan metode penelitian. Pada penelitian Giri dkk. menggunakan metode kohort sedangkan penelitian ini menggunakan metode potong-silang.

Penelitian oleh Jeon ST, dkk. ${ }^{(13)}$ menyatakan terdapat hubungan antara lamanya durasi bermain video game dengan penurunan tajam penglihatan. Selain itu pada orang dewasa yang memiliki mata normal bila bermain video game akan meningkatkan ketajaman dan sensitivitas kontras.

\section{KESIMPULAN}

Penelitian ini diikuti oleh 149 responden dan hasil penelitian adalah 113 responden memiliki visus yang normal, 22 termasuk kedalam penurunan visus hampir normal, 11 termasuk kedalam penurunan visus sedang dan 3 termasuk kedalam penurunan visus berat. Tidak terdapat hubungan bermakna antara intensitas penggunaan game online dengan penurunan visus pada siswa kelas X pada SMAN 23 Tomang Jakarta Barat dengan nilai kemaknaan $p=0.551(p>0.05)$.

Berdasarkan hasil penelitian dan keterbatasan penelitian yang dimiliki maka disarankan dalam penelitian berikutnya duntuk dikembangkan kembali dengan variabel-variabel bebas lainnya yang dapat mempengaruhi penurunan visus responden seperti sosial ekonomi, lingkungan, aktivitas fisik, kebiasaan membaca jarak dekat dan kebiasaan hidup seperti makan-makanan, konsumsi vitamin dan lainnya. Disarankan juga pada penelitian berikutnya menggunakan desain experimental atau kohort dan juga menambah jumlah sampel agar dapat meningkatkan validitas.

\section{UCAPAN TERIMA KASIH}

Dekan Fakultas Kedokteran Universitas Trisakti, dr. Anggraeni adiwardhani Sp.M, sebagai pembimbing akademik, dr. Husnun Amalia,Sp.M selaku kepala bagian mata, dan pihak SMA 23 Tomang Jakarta Barat yang telah membantu hingga selesainya penelitian ini.

\section{DAFTAR PUSTAKA}

1. Anderson, D.M. Dorland's Illustrated medical dictionary. 31st ed. Philadephia: Saunders; 2007; 
25-6

2. Eva R. General Ophtalmology. USA: The Mc Graw-Hill Companies; 2007; 203-15

3. RENSTRANAS PGPK. Rencana strategi nasional penanggulangan gangguan penglihatan dan kebutaan. Jakarta: RenstraNas dan Perdami 2005;2.

4. Riskesdas. Riset Kesehatan Dasar tahun 2013. Jakarta: Badan Penelitian Pengembangan Kesehatan Kementrian RI. 2013. Available at: http://www.depkes.go.id/resources/download/ general/Hasil\%20Riskesdas\%202013.pdf. Accesed Mei, 2017.

5. International Centre for Eye Health. Prevention of childhood blindness. Blindness. 2007;2-4.

6. Dunaway D, Berger I. Worldwide distribution of visual refractive errors and what to expect at a particular location. Available at: http://www. infocusonline.org/worldwide $\% 20$ distribution $\% 20$ of $\% 20$ visual $\% 20$ refractive $\% 20$ error 1 .doc. Accesed Mei, 2017.

7. Hidayah N, Daulay R, Permana LI. Kondisi Penurunan Tajam Penglihatan Anak di SDN Sungai Jingah 4 Banjarmasin. Dinamika Kesehatan. 2016;7(2):185-92.

8. Hanum IF. Efektivitas penggunaan screen pada monitor komputer untuk mengurangi kelelahan mata pekerja call centre di PT Indosat NSR Tahun 2008. (Tesis) Medan: Universitas Sumatera Utara.

9. Giri, KGB, Dharmadi M. Gambaran ketajaman penglihatan berdasarkan intensitas bermain game siswa laki-laki sekolah menengah pertama di wilayah kerja puskesmas Gianyar 1 Bulan Maret April 2013. E-Jurnal Medika Udayana. 2015; 4(1). DOI 10.24922/eum

10. Qomariyah AN. Perilaku penggunaan internet pada kalangan remaja di perkotaan. Jurnal Palimpsest 2009;1(1):87-100.

11. Mondal K, Manna N, Dasgupta U, Chakraborty A, Biswas S, Mundle M. A Study of visual acuity among the students in a rural girls high school of West Bengal. IOSR-JDMS 2017;10(2):12-6. DOI: 10.9790/0853-01021216

12. Tina $Y$, Cindy $X$, Raiju J, Babu, Joanna $M$, et al. Effectiveness of a binocular video games vs placebo game for improving visual functions in older children, teenagers and adults with amblyopia. JAMA Opthalmol 2018;136(2); E1-10. doi:10.1001/jamaophthalmol.2017.6090

13. Jeon ST, Maurer D, Lewis TL. The effect of video game training on the vision of adults with bilateral deprivation amblyopia. Seeing and Perceiving 2012;25(5):493-520. DOI: $10.1163 / 18784763$ 00002391 